\title{
Flesh firmness examination of scab-resistant apple varieties in a storage experiment
}

\author{
Mihály Orosz-Tóth - Sándorné Kincses \\ University of Debrecen, Faculty of Agricultural and Food Sciences and Environmental Management, Institute of Agricultural Chemistry and \\ Soil Science, Debrecen \\ otmisi@gmail.com
}

SUMMARY

Of the different physical characteristics of fruits, one of the most essential qualities is flesh firmness, as is an important parameter when selling fresh apples, processing the fruit (processing industry) and during its storage. In the scope of our research, we examined five apple varieties originating from the Derecske horticultural site of KITE cPlc. in 2016. The plantation was planted to be suitable for intensive apple production. Samples were collected at the time of maturity (August-October) of the given variety. The five examined apple varieties (Gaia, Isaaq, Modi, Smeralda and Fujion) are all resistant to apple scab (fungal disease caused by Venturia inaequalis). The two-month storage experiment was conducted at $16-17^{\circ} \mathrm{C}$, which had an aggressive effect on our stored apples. Flesh firmness, weight and diameter were measured on three dates for each of the five apple varieties. Our results were evaluated using IBM SPSS Statistics 20 software. We aimed to compare flesh firmness, weight and diameter of the five apple varieties and their changes during storage. Isaaq $\left(86.34 \mathrm{~N} / \mathrm{cm}^{2}\right), \mathrm{Modi}\left(94.06 \mathrm{~N} / \mathrm{cm}^{2}\right)$ and Fujion $\left(84.90 \mathrm{~N} / \mathrm{cm}^{2}\right)$ had outstanding initial flesh firmness results. The Modi apple variety provided the best storage parameters.

Keywords: flesh firmness, penetrometer examination, storage

\section{INTRODUCTION}

Due to the favourable conditions of apple growing, apple has the largest production area in Hungary among fruits. The most important of the many benefits of apples is that they can be stored for a longer period of time, therefore they can be consumed fresh throughout the year. (Laczkovszki, 2012) Considering the market situation, apple growers also prefer apple varieties suitable for long-term storage, such as Idared (Inántsy and Balázs, 2004). All of the 5 examined apple varieties (Gaia, Isaaq, Modí, Smeralda, Fujion) are resistant to scabbing, which is caused by Venturia inequalis (Cooke, 2000). The fungus infects mainly during the rainy season, after which the symptoms appear on the leaves, flowers and fruits of the apple tree (Tóth, 2013).

Flesh firmness is an important qualitative parameter of fruits, and penetrometric methods can be used to measure them. The term firmness refers to the resistance of a material to the pressure head penetrating the test specimen (Felföldi, 2007). In general, firmness is characterized by force and deformation (Fekete et al., 2002). Using a handheld penetrometer, apple flesh is penetrated and its resistance is measured. According to Tukey and Young (1942), the cortex and the stele, are located below the epidermis. It is a part of the flesh of apple, which is made up mainly of parenchyma cells (Smith, 1950). The middle lamella is situated between the cell walls of the parenchyma cells and it is rich in pectin. The cell wall and the middle lamella are actually a cross-linked structure made of cellulose and pectin (Kállay, 2010), which greatly influences flesh firmness.

The primary cause of flesh softening is that the cell wall structure is altered and the amount of watersoluble pectin in tissues increases. This process is caused by the activity of the pectinesterase and polygalacturonase enzymes (Kállay, 2010). The process also involves the pectate lyase enzyme, which is responsible for the cleavage of de-esterified $\mathrm{Ca}^{2}+$ bound pectin chains. In addition to these pectindegrading enzymes, apple lesh softening is affected by autocatalytic ethylene synthesis, climacteric respiration (Fidler, 1973) and starch content decomposition.

Apples lose weight during storage, which is known as diminution. Some biological and physical factors, such as apple respiration and volatile matter production, skin tissue structure, respiratory-lenticellar functionality, diffusion resistance, humidity, temperature and flow rate of ambient air all play a role in diminution (Kállay, 2010). In the present study, we examined the weight and firmness of our apples during storage by increasing the temperature.

Our goal is to collect information on the usability and some of the properties of the scab resistant varieties (Gaia, Isaaq, Modí, Smeralda and Fujion) that have been marketed in the last decade. Our questions: What is the difference in the flesh firmness of these apple varieties? How does storage change flesh firmness and weight? Does weight affect flesh firmness?

\section{MATERIALS AND METHODS}

In 2016, in our storage experiment, we examined the yield of scab-resistant apple trees from an apple plantation. The 2-month storage experiment was set up in the storage of the DE MÉK Institute of Agrochemistry and Soil Science, where we measured the firmness of the apple varieties at their harvest/initial phase and after the first and second months. In addition to flesh firmness, our measurements involved other physical parameters of the apples, such as height, width and weight, which were measured with a calliper and analytical scale. Storage temperature was set at 16-17 ${ }^{\circ} \mathrm{C}$ to induce a radical softening effect.

\section{Area, apple trees, plantation data}

The five apple varieties of the Derecskei horticultural site of KITe cPlc are Gaia, Isaaq, Modí, 
Smeralda and Fujion. These varieties were bred in Italy and all of them are resistant to scabbing. Their picking time is consistent with their listed order. The apple trees were planted in 2014 with a support system, hail net and a drip irrigation system. The intensive plantation is formed on M.9 subject, in spindle form. Chemical and mechanical processes are also used in the plantation. Plant protection and nutrient supply shall be carried out in accordance with integrated principles. Annual pruning take place during the late winter. The physical nature of the soil is sand and its $\mathrm{pH}$ is slightly acidic and lime-deficient. Based on the humus content, its $\mathrm{N}$ supply is moderate, while its $\mathrm{P}$ - and $\mathrm{K}$-supply is very good (Gonda and Apáti, 2013). Table 1 shows the most important physical chemical properties of soil.

\section{Nutrient supply}

The soil is slightly acidic and therefore the micronutrient supply was solved by foliar fertilization. The following table (Table 2) shows the nutrient supply program.

Soil data of the plantation at the Derecske horticultural site of KITE cPlc

\begin{tabular}{ccccccccc}
\hline Depth $[\mathbf{c m}]$ & $\mathbf{K}_{\mathbf{A}}$ & Humus $[\mathbf{m} / \mathbf{m} \%]$ & $\begin{array}{c}\mathbf{P}_{\mathbf{2}} \mathbf{O}_{\mathbf{5}} \\
{\left[\mathbf{m g ~ k g}^{-\mathbf{1}}\right]}\end{array}$ & $\begin{array}{c}\mathbf{K}_{\mathbf{2}} \mathbf{O} \\
{\left[\mathbf{m g ~ k g}^{-1}\right]}\end{array}$ & lime $[\mathbf{m} / \mathbf{m} \%]$ & $\mathbf{y}_{\mathbf{1}}$ & $\mathbf{p H}_{\mathbf{K C l}}$ & $\mathbf{p H}_{\mathbf{H} 20}$ \\
\hline $0-20$ & 25 & 0.9 & 281 & 330 & $<0.1$ & 8.8 & 5.50 & 6.51 \\
$20-40$ & 25 & 0.9 & 325 & 308 & $<0.1$ & 10.3 & 5.26 & 6.27 \\
$40-60$ & 25 & 0.7 & 85 & 187 & $<0.1$ & 12.0 & 4.45 & 5.63 \\
\hline
\end{tabular}

Nutrient supply program

\begin{tabular}{lccc}
\hline & Distribution & & \multicolumn{2}{c}{$\begin{array}{c}\text { Fertilization requirement }\left(\mathbf{k g ~ h a} \mathbf{~}^{-1}\right) \\
\text { monopotassium phosphate }\end{array}$} \\
\hline $\begin{array}{l}\text { ammonium-nitrate } \\
\text { calcium-nitrate }\end{array}$ & $2 \mathrm{x}$ & 56 & 78 \\
$\begin{array}{l}\text { After fruit set } \\
\text { Fruit growth } \\
\text { (only until the middle of July) }\end{array}$ & $6 \mathrm{x}$ & 56 & 24 \\
Autumn & $1 \mathrm{x}$ & 169 & 32 \\
\hline
\end{tabular}

\section{Meteorological factors}

Annual precipitation amounts, temperatures (average, maximum, minimum) and the number of sunny hours at the Derecske horticultural site of KITE cPlc. are summarized in Table 3. According to multiple years of climate data in Hungary, heavy rainfall fell in 2016, but the number of sunny hours was lower.

Table 3

Temperature and precipitation (Derecske, Debrecen-Pallag)

\begin{tabular}{lc}
\hline \multicolumn{2}{c}{ Derecske horticultural site of KITE cPlc. } \\
\hline Measurement year & 2016 \\
Minimum temperature $\left({ }^{\circ} \mathrm{C}\right)$ & -11.45 \\
Maximum temperature $\left({ }^{\circ} \mathrm{C}\right)$ & 43.66 \\
Mean temperature $\left({ }^{\circ} \mathrm{C}\right)$ & 13.75 \\
Precipitation amount $(\mathrm{mm})$ & 722 \\
Number of sunny hours & 2372 \\
\hline
\end{tabular}

\section{Sampling}

Samples were collected in 2016 according to the ripening time of the given varieties (Table 4). According to a representative sampling, 4-5 kg were collected three times from each variety, so we could perform the flesh firmness examination in 6 replications. 5-5 apples were randomly selected from the formed groups (replicates) and the measurements were performed on them.

Table 4

Sampling dates

\begin{tabular}{cccccc}
\hline & Gaia & Isaaq & Modí & Smeralda & Fujion \\
\hline 2016 & 08.29 & 09.09 & 09.09 & 10.13 & 10.27 \\
\hline
\end{tabular}

\section{Penetrometer examination}

A handheld penetrometer was used to examine the flesh firmness. This instrument has a cylindrical probe that puts pressure on the fruit by pulling down a lever. Removing the skin of the apple on a thin width of 1.5$2 \mathrm{~cm}$, the apple flesh is penetrated on 3 different points, near the peduncle, on the side of the fruit and on the bottom of the fruit. There is a marking line on the probe, which indicates how long to penetrate the fruit. With the help of the force sensor, the instrument can provide the desired force to penetrate the fruit. Results are expressed in kilopond, which are converted to $\mathrm{N} / \mathrm{cm}^{2}$. The greater the force acting on the fruit, the greater the degree of tissue destruction. The harder the flesh of the fruit, the greater the force required to penetrate. 


\section{Statistics}

The measured data were recorded in the MS Excel spreadsheet software. For single-factor analysis of variance, IBM SPSS Statistics 20 was used. Tukey's test was used for analysis. Signals from the SPSS software are shown in the figures below.

\section{RESULTS AND DISCUSSION}

Figure 1 shows the size of apple varieties together with their diameters. On the basis of the obtained sizes,
Gaia and Isaaq varieties can be classified as smaller apples. Modí, Smeralda and Fujion are among the larger apples. Diameters of the apple varieties were measured only at the initial stage as they hardly change during storage. The shape of the apples was obtained using the shape index, which is calculated by the ratio of height to width. According to the shape indexes obtained, Modí (0.99) is the most round apple, since their average height and width are almost identical.

Figure 1: Size of apple varieties

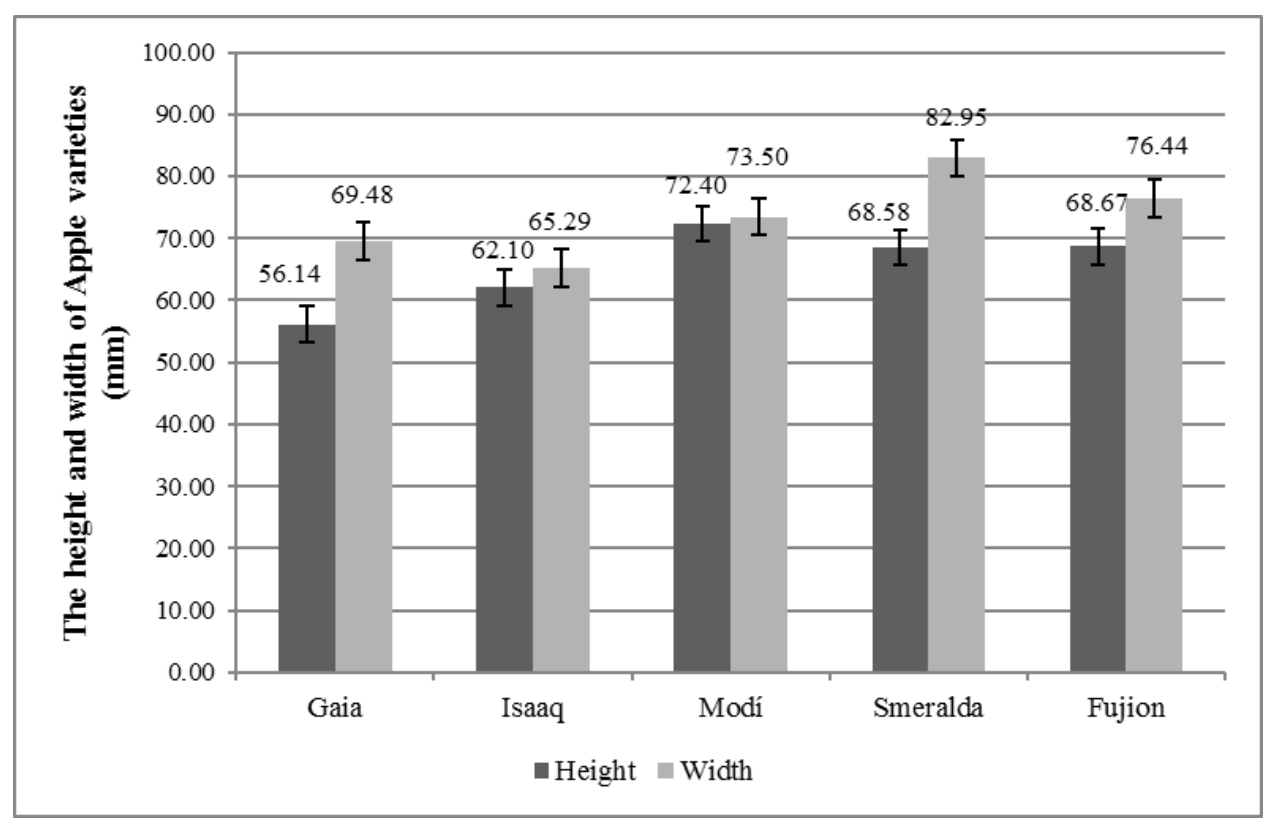

Shape index: Gaia-0.81; Isaaq-0.95; Modí-0.99; Smeralda-0.83; Fujion-0.90

Figure 2 shows the change of flesh firmness of the apple varieties during two months of storage. The result of the drastic softening process is shown, which is due to the temperature of $16-17^{\circ} \mathrm{C}$. In general, the figure shows that the values of all apple varieties show a decreasing tendency. In all 3 measurements, the Modí and Isaaq apple varieties have the highest flesh firmness. During the 2 month storage, Gaia always had the lowest value. Statistically, 4-4 groups can be separated on each of the three measurement times. In the case of Fujion, a greater significant decrease can be found, since in the first measurement it is to be classified in the same group with Isaaq for the first measurement and with Smeralda for the second measurement.
Table 5 shows the changes in terms of the flesh firmness of the apple varieties and their statistical evaluation over storage time. It can be stated with certainty that there is a significant difference between the measurements of all apple varieties. Due to the drastic storage conditions, Gaia is negatively exceeded, while and Smeralda and Fujion approached the critical value of $50 \mathrm{~N} / \mathrm{cm}^{2}$, during which the softening process is so advanced that its fresh consumption can no longer be enjoyed. After two months of storage, only the Modí apple variety $\left(59.32 \mathrm{~N} / \mathrm{cm}^{2}\right)$ does not reach the critical flesh firmness value. 
Figure 2: Development of the flesh firmness of apple varieties with regard to their measurement

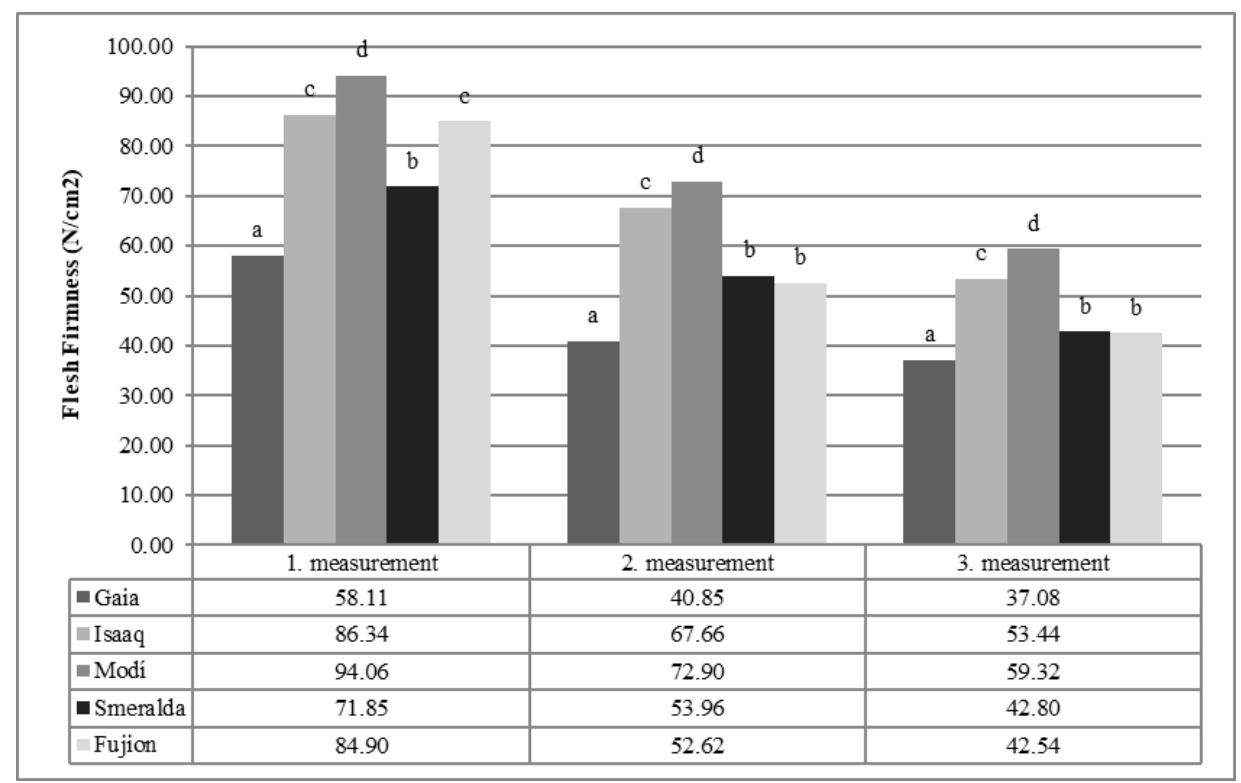

Flesh firmness of apple varieties

\begin{tabular}{lccccc}
\hline & Gaia & Isaaq & Modí & Smeralda & Fujion \\
\hline 1. measurement & $58.11 \mathrm{c}$ & $86.34 \mathrm{c}$ & $94.06 \mathrm{c}$ & $71.85 \mathrm{c}$ & $84.9 \mathrm{c}$ \\
2. measurement & $40.85 \mathrm{~b}$ & $67.66 \mathrm{~b}$ & $72.9 \mathrm{~b}$ & $53.96 \mathrm{~b}$ & $52.62 \mathrm{~b}$ \\
3. measurement & $37.08 \mathrm{a}$ & $53.44 \mathrm{a}$ & $59.32 \mathrm{a}$ & $42.8 \mathrm{a}$ & $42.54 \mathrm{a}$ \\
\hline
\end{tabular}

The change in the weight of the five apple varieties is shown in Figure 3. Smeralda has the highest weight in terms of the three measurements; the smallest are the Isaaq and Gaia apple varieties. Considering the results of measurements taken at different times, the weights of Isaaq and Gaia are not statistically different. Statistically, apple varieties are classified into 4-4 groups for each measurement and the composition of the groups does not change.

Figure 3: Development of the weight of apple varieties

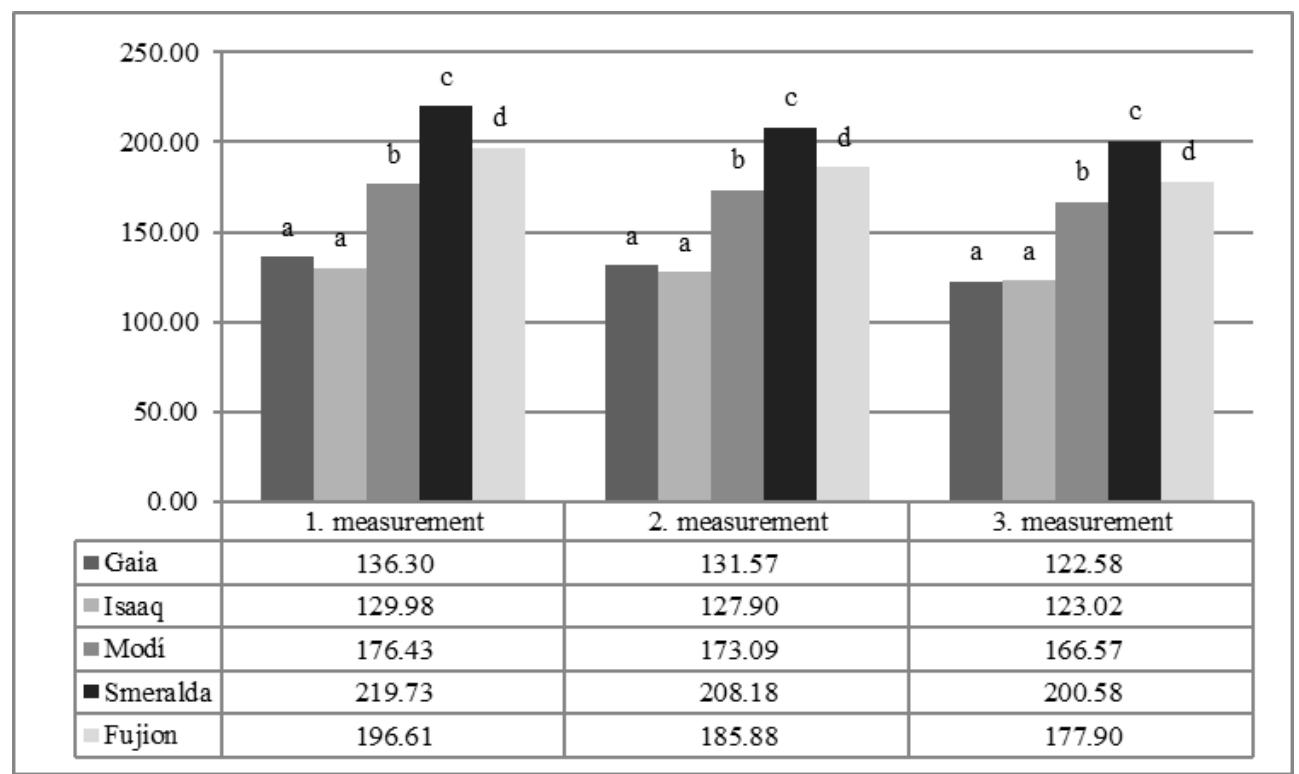


Table 6 shows the weight change and statistical evaluation of scab resistant apple varieties during storage. Based on the data shown in the table it can be stated that all stored apple varieties have lost weight. Significant difference was found among the mean values of the Fujion variety. Within the other four varieties, the 3 results are classified into 2 groups, but the first and third measurements are in separate groups, so the weight of all apple varieties decreased significantly during the 2-month storage period.

Weight (g)

Table 6

\begin{tabular}{lccccc}
\hline & Gaia & Isaaq & Modí & Smeralda & Fujion \\
\hline 1. measurement & $136.3 \mathrm{~b}$ & $129.98 \mathrm{~b}$ & $176.43 \mathrm{~b}$ & $219.73 \mathrm{~b}$ & $196.61 \mathrm{c}$ \\
2. measurement & $131.57 \mathrm{~b}$ & $127.9 \mathrm{ab}$ & $173.09 \mathrm{ab}$ & $208.18 \mathrm{a}$ & $185.88 \mathrm{~b}$ \\
3. measurement & $122.58 \mathrm{a}$ & $123.02 \mathrm{a}$ & $166.57 \mathrm{a}$ & $200.58 \mathrm{a}$ & $177.9 \mathrm{a}$ \\
\hline
\end{tabular}

In Figure 4, we compared the flesh firmness and weight values to see if there is a correlation between the weight and flesh firmness of the examined apple varieties. Based on the diagram, we conclude that there is no clear correlation between these two data. We expected an inverse proportionality between the values, ie the higher the weight of the apple, the lower the firmness of the flesh. Our results did not prove this. According to the figure, Gaia has a lower weight (136.3 g) and is associated with the lowest firmness value $\left(58.11 \mathrm{~N} / \mathrm{cm}^{2}\right)$ out of the five apple varieties.

Figure 4: Correlation of weight and flesh firmness

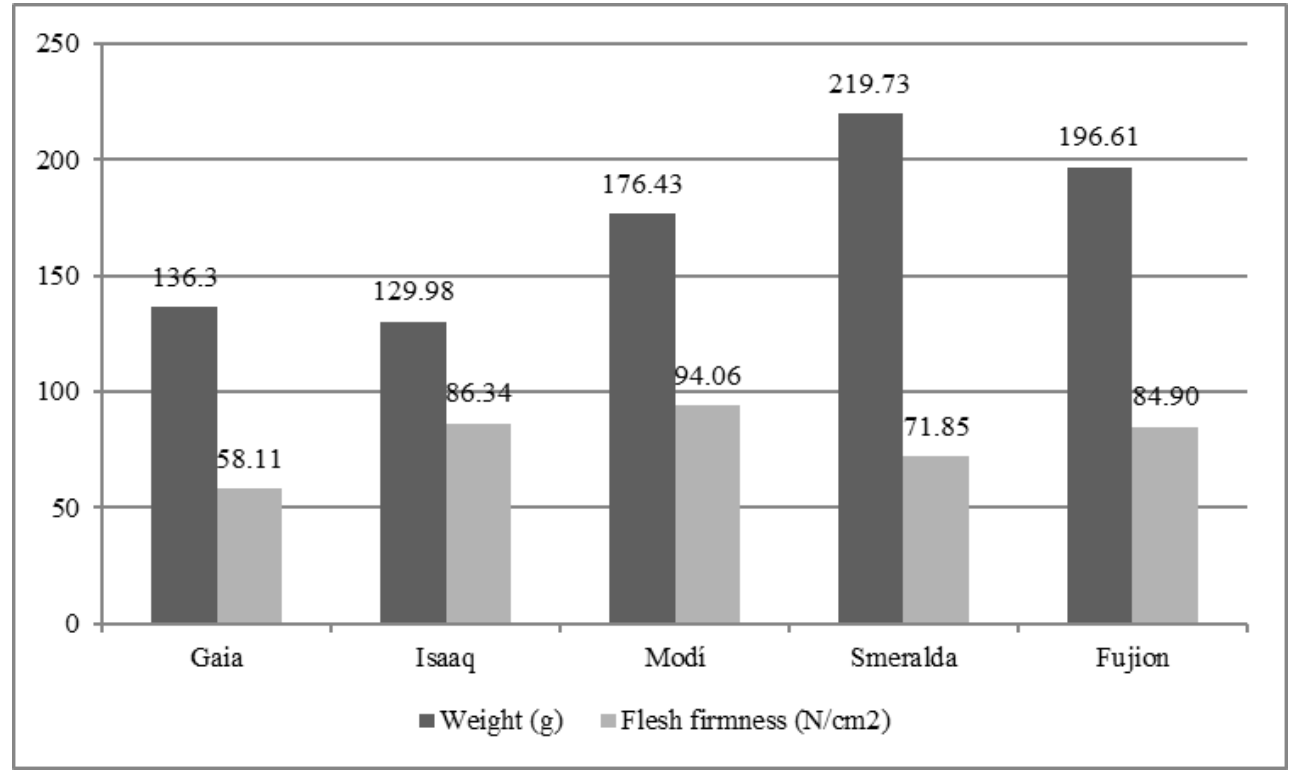

\section{CONCLUSIONS}

The weight and flesh firmness of every scabresistant apple variety decreased significantly during 2 months of storage. From among the 5 varieties of apples originating from Italy, Modí has the best storage capacity, as it does not reach the critical flesh firmness value of $50 \mathrm{~N} / \mathrm{cm}^{2}$ after 2 months. Gaia is recommended for immediate fresh consumption or processing. Further testing is required for other apple varieties in terms of use (eg controlled atmosphere storage).

Usually, the firmness of resistant apple varieties is higher compared to non-resistant apple varieties because of their harder texture (Tóth, 2013). Nevertheless, the firmness of our apple varieties varied. Based on our results no proven correlation can be drawn between the weight and the firmness of our apple varieties. Other factors also need to be examined to obtain a more comprehensive picture of apple firmness, such as tissue/structural examinations. 


\section{REFERENCES}

Cooke, M.S.-Evans, M.D.-Herbert, K.E.-Lunec, J. (2000): Urinary 8-oxo-2'-deoxyguanosine--source, significance and supplements. Free Radic Res. 32(5): 381-397.

Fekete, A.-Felföldi, J.-Borsa, B. (2002): Kertészeti termények mechanikai és minőségi jellemzői- Mezőgazdasági Gépesítési Tanulmányok- Az FVM Müszaki Intézet közleménye, Gödöllő, XLI. évfolyam, 2. szám

Felföldi, J. (2007): Minőségvizsgálatok és élelmiszer-biztonság. In Barta, J. (szerk.): A gyümölcsfeldolgozás technológiái. Mezőgazda Kiadó, Budapest. 248-258.

Fidler, J.C. (1973): Basic physiology (In Fidler et al.: The biology of apple and pear storage. Commonwealth Agricultural Bureau (C.A.B.) 5

Gonda, I.-Apáti, F. (2013): Versenyképes almatermesztés. Szaktudás Kiadó Ház Zrt., Budapest. 31., 134-144.
Inántsy, F.-Balázs, K. (2004): Integrált növénytermesztés- ALMA. Agroinform Kiadó, Budapest. 69 p., 58-65.

Kállay, T. (2010): Az almatárolás biológiai alapjai. Mezőgazda Kiadó, Budapest. 7-9.

Laczkovszki, Cs. (2012): Gyümölcstermesztés. Magyar Agrárkamara, Budapest. 1-238. . ISBN 9786155307065

Smith, W.H. (1950): Cell multiplication and cell enlargement in the development of the flesh of the apple fruit. Annals of Botany N. S. (14) 53. 23-38.

Tóth, M. (2013): Magyarország kultúrflórája- Az alma. Agroinform Kiadó, Budapest.

Tukey, H.B.-Young, J.O. (1942): Gross morphology and histology of the developing fruit of the apple. Botanical Gazette 104. p. 125 . 